\title{
PENGARUH KOMPETENSI, INDEPENDENSI, DAN PROFESIONAL AUDITOR TERHADAP KUALITAS AUDIT
}

\author{
Lia Dahlia dan Ellyn Octavianty \\ Dosen Tetap Fakultas Ekonomi Universitas Pakuan
}

\begin{abstract}
ABSTRAK
Kualitas audit sangat penting, di mana semakin tinggi kualitas audit yang diterapkan akan menghasilkan laporan keuangan akurat dan dapat dipercaya sebagai dasar pengambilan keputusan bagi para pemakai laporan keuangan tersebut. Tujuan penelitian ini adalah untuk mengetahui pengaruh kompetensi, independensi dan profeionalisme auditor terhadap kualitas audit. Metode pengolahan dengan uji validitas, reliabilitas, analisis regresi linier berganda, uji hipotesis, dan uji koefisien determinasi. Hasil penelitian menunjukkan kompetensi auditor dalam melaksanakan audit berpengaruh positif dan signifikan terhadap kualitas audit pada KAP di Jakarta Selatan. Independensi auditor dalam melaksanakan audit berpengaruh positif dan signifikan terhadap kualitas audit pada KAP. Sedangkan Profesionalisme auditor dalam melaksanakan audit berpengaruh positif dan signifikan terhadap kualitas audit pada KAP.
\end{abstract}

Kata kunci: kompetensi, indepedensi, profesionalisme, dan kualitas audit.

\begin{abstract}
Audit quality is very important, where the higher the quality audit that is applied to produce financial statements accurate and reliable as a basis for decision making for the users of these financial statements. The purpose of this study was to determine the effect of competence, independence and profeionalisme auditor to audit quality. Processing method to test the validity, reliability, multiple linear regression, hypothesis testing, and test the coefficient of determination. The results showed the competence of auditors in carrying out audits and significant positive effect on audit quality in KAP in South Jakarta. Independence of the auditor in carrying out audits and significant positive effect on audit quality in KAP. While Professionalism auditor in carrying out audits and significant positive effect on audit quality in KAP.
\end{abstract}

Keywords: competence, independency, professionalism, and quality audits.

\section{Pendahuluan}

Manajamen dan pemegang saham pengendali dalam suatu perusahaan memerlukan jasa pihak ketiga untuk menegaskan bahwa laporan keuangan yang dibuat oleh manajemen perusahaan dapat dipertanggungjawabkan kepada pemangku kepentingan (stakeholders). Maka dari itu, manajemen perusahaan dan pemegang saham pengendali memerlukan jasa pihak ketiga yang dapat dipercaya, sehingga diperlukan profesi audit dan Kantor Akuntan Publik (KAP). Profesi audit dan Kantor Akuntan Publik merupakan profesi kepercayaan masyarakat. Hal ini karena profesi akuntan publik memiliki penilaian yang bebas dan tidak memihak pada manajemen perusahaan atas informasi yang disajikannya dalam laporan keuangan. Salah satu manfaat dari jasa akuntan publik adalah memberikan informasi yang akurat dan dapat dipercaya untuk pengambilan keputusan. Laporan keuangan yang telah diaudit oleh akuntan publik kewajarannya lebih dapat dipercaya dibandingkan laporan keuangan yang tidak atau belum diaudit.

Pengguna laporan audit mengharapkan bahwa laporan keuangan yang telah diaudit oleh akuntan publik dapat akurat, bebas dari salah saji material, dan dapat dipercaya 
kebenarannya untuk dijadikan sebagai dasar pengambilan keputusan dan sesuai dengan prinsip akuntansi berlaku umum di Indonesia. Oleh karena itu, diperlukan suatu jasa profesional yang independen dan obyektif untuk menilai kewajaran laporan keuangan yang disajikan oleh manajemen perusahaan.

Publik semakin mempertanyakan kualitas audit yang dihasilkan oleh para auditor seiring dengan maraknya kasuskasus yang terjadi baik di dalam negeri maupun di mancanegara, dimana kasuskasus tersebut berkaitan dengan pelanggaran yang dilakukan oleh para auditor. Hal ini dapat mengancam kredibilitas laporan keuangan yang dapat mempengaruhi persepsi masyarakat, khususnya pemakai laporan keuangan atas kualitas audit.

Kepercayaan yang besar dari pemakai laporan keuangan auditan dan jasa lainnya yang diberikan akhirnya mengharuskan akuntan publik memperhatikan kualitas audit yang dihasilkannya. Adapun pertanyaan dari masyarakat tentang kualitas audit yang dihasilkan oleh akuntan publik semakin besar, setelah terjadi banyak skandal yang melibatkan akuntan publik. Seperti kasus yang menimpa akuntan publik Justinus Aditya Sidharta yang diindikasi melakukan kesalahan dalam mengaudit laporan keuangan PT Great River Internasional, Tbk. Oleh karenanya, Menteri Keuangan RI terhitung sejak tanggal 28 November 2006 telah membekukan izin akuntan publik Justinus Aditya Sidharta selama dua tahun karena terbukti melakukan pelanggaran terhadap Standar Profesi Akuntan Publik (SPAP) atas Laporan Keuangan Konsolidasi PT Great River tahun 2003 (Elfarini, Christina, 2007).

Terjadinya pelanggaran terhadap Standar Profesi Akuntan Publik (SPAP) yang dilakukan akuntan publik Justinus Aditya Sidharta disebabkan akuntan publik tersebut tidak menerapkan standar audit yang meliputi: 1) Audit harus dilaksanakan oleh seorang atau lebih yang memiliki keahlian dan pelatihan teknis yang cukup; dan 2) Dalam semua hal yang berhubungan dengan perikatan, independensi dalam sikap mental harus dipertahankan oleh auditor.

Penelitian yang dilakukan oleh KAP "Big Four" di Indonesia, Singgih, Muliani dan Bawono (2010) menyimpulkan bahwa independensi, pengalaman, due professional care dan akuntabilitas secara simultan berpengaruh terhadap kualitas audit. Independensi, due professional care dan akuntabilitas secara parsial berpengaruh terhadap kualitas audit, sedangkan pengalaman tidak berpengaruh terhadap kualitas audit. Hasil penelitian Tjun, Indrawati \& Setiawan (2012) adalah kompetensi berpengaruh terhadap kualitas audit, sedangkan independensi tidak berpengaruh terhadap kualitas audit. Dalam kualitas audit saat ini menjadi sesuatu yang sangat penting karena hasil audit digunakan oleh banyak pihak dan digunakan untuk mengambil keputusan.

Selain diharapkan mempunyai kompetensi dan independensi di bidangnya, para auditor juga diharapkan mempunyai profesionalisme yang tinggi dalam melaksanakan tanggung jawabnya. Profesionalisme adalah sikap atau semangat mempertahankan suatu profesi dan memelihara citra publik terhadapnya serta menekuni ilmu dan substansi pekerjaan dalam bidang tersebut (Anita Kusuma Dewi, 2010). Pemberian kepercayaan kepada auditor dengan memberikan peran yang lebih besar untuk memeriksa entitas tempat mereka bekerja telah menjadi bagian penting dalam proses terciptanya akuntabilitas publik. Seorang auditor yang profesional akan mempertimbangkan material atau 
tidaknya informasi dengan tepat, karena hal ini berhubungan dengan jenis opini yang akan diberikan. Semakin auditor menyadari akan tanggung jawab profesionalnya maka Kualitas Audit akan terjamin dan terhindar dari tindakan manipulasi. Jadi dapat disimpulkan bahwa Profesionalisme Auditor juga mempunyai peran yang penting dalam pelaksanaan dan Kualitas Audit.

Adapun tujuan yang ingin dicapai dalam penelitian ini adalah sebagai berikut: 1) Untuk mengetahui kompetensi auditor terhadap kualitas audit; 2) Untuk mengetahui independensi auditor terhadap kualitas audit; 3) Untuk mengetahui profesionalisme auditor terhadap kualitas audit; dan 4) Untuk mengetahui pengaruh kompetensi, independensi dan profeionalisme auditor secara bersamasama terhadap kualitas audit.

\section{Landasan Teori}

\subsection{Teori Pengharapan}

Teori pengharapan (expectancy theory) pertama kali dikembangkan oleh Vroom pada tahun 1964. Dalam teori ini, Vroom lebih menekankan pada faktor hasil (outcomes), ketimbang kebutuhan (needs). Vroom mengemukakan bahwa orang-orang akan termotivasi untuk melakukan hal-hal tertentu guna mencapai tujuan apabila mereka yakin bahwa tindakan mereka akan mengarah pada pencapaian tujuan tersebut. Teori harapan ini didasarkan atas:

1. Harapan (expectancy): Suatu kesempatan yang diberikan akan terjadi karena perilaku atau suatu penilaian bahwa kemungkinan sebuah upaya akan menyebabkan kinerja yang diharapkan.

2. Nilai (value): Hasil dari seberapa jauh seseorang mengingkan imbalan/signifikansi yang dikaitkan oleh individu tentang hasil yang diharapkan.
3. Pertautan (instrumentality): persepsi dari individu bahwa hasil tingkat pertama ekspektasi merupakan sesuatu yang ada dalam diri individu yang terjadi karena adanya keinginan untuk mencapai hasil sesuai dengan tujuan atau keyakinan bahwa kinerja akan mengakibatkan penghargaan.

Dari teori pengharapan tersebut, motivasi auditor adalah untuk menyelesaikan tugas audit tepat waktu dan sesuai tujuan untuk memenuhi harapan dari pihak pengguna.

\subsection{Kompetensi}

Standar umum pertama pada PSA 210.1 SPAP (IAI, 2011) menyebutkan bahwa audit harus dilaksanakan oleh seorang atau lebih yang memiliki keahlian dan pelatihan teknis yang cukup sebagai auditor. Betapapun tingginya kemampuan seseorang dalam bidang-bidang lain, termasuk dalam bidang bisnis dan keuangan, ia tidak dapat memenuhi persyaratan yang dimaksudkan dalam standar auditing ini, jika ia tidak memiliki pendidikan serta pengalaman memadai dalam bidang auditing.

Untuk menyatakan seseorang telah memenuhi standar umum yang pertama, ia harus dapat memenuhi persyaratan dimana terdapat 3 faktor, yaitu: (1) Pengetahuan, (2) Keahlian khusus dan (3) Pengalaman. Hal inilah yang peneliti gunakan untuk menjadi indikator dalam menilai Kompetensi auditor.

\subsection{Independensi}

Independensi menurut Arens et al (2012:111) dapat diartikan mengambil sudut pandang yang tidak bias. Auditor tidak hanya harus independen dalam fakta, tetapi juga harus independen dalam penampilan. Independensi dalam fakta (independence in fact) ada bila 
auditor benar-benar mampu mempertahankan sikap yang tidak bias sepanjang audit, sedangkan independensi dalam penampilan (independent in appearance) adalah hasil dari interpretasi lain atas independensi ini.

Pada penelitian ini peneliti mengukur independensi diukur dengan cara, yaitu: (1) Lama hubungan dengan klien, (2) Tekanan dari klien, (3) Telaah dari rekan auditor dan (4) Pemberian jasa non audit.

\subsection{Profesionalisme}

Menurut Standar Profesional Akuntan Publik SA Seksi 230 (IAPI, 2011), standar umum ketiga berbunyi: "Dalam pelaksanaan audit dan penyusunan laporannya, auditor wajib menggunakan kemahiran profesionalnya dengan cermat dan saksama". Standar ini menuntut auditor independen untuk merencanakan dan melaksanakan pekerjaannya dengan menggunakan kemahiran profesionalnya secara cermat dan saksama. Penggunaan kemahiran profesional dengan kecermatan dan kesaksamaan menekankan tanggung jawab setiap profesional yang bekerja dalam organisasi auditor independen untuk mengamati standar pekerjaan lapangan dan standar pelaporan. Penggunaan keahlian profesional dengan cermat dan saksama menyangkut apa yang dikerjakan auditor dan bagaimana kesempurnaan pekerjaannya tersebut.

\subsection{Kualitas Audit}

Berdasarkan Standar Profesional Akuntan Publik (SPAP) (IAI, 2011) audit yang dilaksanakan oleh seorang auditor dapat dikatakan berkualitas jika memenuhi ketentuan atau standar auditing yang berlaku umum (generally accepted auditing standards = GAAS) dan standar pengendalian mutu. Standar auditing tersebut dijadikan acuan auditor dalam memenuhi tanggung jawab profesionalnya dalam melaksanakan audit atas laporan keuangan. Auditor harus memiliki kualitas audit yang memadai sehingga dapat mengurangi ketidakselarasan yang terjadi antara manajemen dengan pemegang saham, karena pengguna laporan keuangan terutama pemegang saham akan mengambil keputusan berdasarkan pada laporan yang telah diaudit oleh auditor.

Dari pengertian tentang kualitas audit di atas maka dapat disimpulkan bahwa kualitas audit merupakan kemungkinan auditor menemukan pelanggaran dalam sistem akuntansi dan pencatatannya pada laporan keuangan yang disajikan oleh pihak manajemen, auditor juga harus mampu mengungkapkan atas pelanggaran tersebut dalam laporan keuangan auditan demi mempertahankan independensinya. Dan menerapkan kemampuannya dengan cermat dan tepat, dalam hal ini auditor berpedoman kepada standar auditing dan kode etik akuntan publik yang relevan.

\section{Metodologi Penelitian \\ 3.1. Metode Penarikan Sampel}

Penelitian ini menggunakan sampel data kuesioner yang diperoleh dari jawaban dari responden dalam hal ini yaitu auditor KAP yang berada di Jakarta Selatan. Adapun metode yang digunakan adalah nonprobability sampling dimana anggota populasi tidak memiliki peluang yang sama untuk terpilih menjadi sampel bagi. Sedangkan teknik pengambilan sampel yang digunakan adalah Convinience sampling atau pengumpulan informasi dari anggota populasi yang dengan senang hati bersedia memberikannya. Teknik ini digunakan karena peneliti tidak memiliki data pasti mengenai jumlah auditor yang ada di Kantor Akuntan Publik di Jakarta Selatan. Terlampir nama-nama KAP di Jakarta Selatan yang terdaftar per 30 Oktober 2015 di Pusat Pembinaan 
Akuntan dan Jasa Penilai (PPAJP) Kemenkeu RI, sebagaimana terdapat pada (Lampiran 1).

\subsection{Metode Pengumpulan Data}

Pengumpulan data yang dilakukan oleh penulis ialah dengan menggunakan data primer. Data primer adalah data yang diperoleh langsung yang bersumber dari jawaban kuesioner dari responden yang akan dikirim secara langsung kepada auditor dari KAP di Jakarta Selatan.

Data dikumpulkan melalui metode angket, yaitu menyebarkan daftar pertanyaan (kuesioner) yang akan diisi atau dijawab oleh responden auditor pada KAP di Jakarta Selatan. Kuesioner tersebut terdiri dari dua bagian. Bagian pertama berisi sejumlah pertanyaan yang bersifat umum. Bagian kedua, berisi sejumlah pertanyaan yang berhubungan dengan kompetensi dan independensi auditor.

Kuesioner diberikan secara langsung kepada responden. Responden diminta untuk mengisi daftar pertanyaan tersebut, kemudian memintanya untuk mengembalikannya melalui peneliti yang secara langsung akan mengambil angket yang telah diisi tersebut pada KAP yang bersangkutan. Angket yang telah diisi oleh responden kemudian diseleksi terlebih dahulu agar angket yang tidak lengkap pengisiannya tidak diikutsertakan dalam analisis.

Pengukuran variabel-variabel menggunakan instrumen berbentuk pertanyaan tertutup. Instrumen pertanyaan yang berhubungan dengan variabel independen yang diteliti serta diukur menggunakan skala Likert dari 1 s/d 5. responden diminta memberikan pendapat setiap butir pertanyaan, mulai dari sangat tidak setuju sampai sangat setuju.

Nilai jawaban ini berlaku juga untuk butir pertanyaan yang sifatnya negatif, hanya saja jawaban responden dibalik. Jika responden menjawab pertanyaan dengan nilai 5, maka jawaban tersebut diubah menjadi nilai 1 , nilai 4 diubah menjadi nilai 2 , tetapi nilai 3 tetap.

\subsection{Metode Pengolahan/Analisis Data}

Adapun uji yang digunakan dalam penelitian ini adalah dengan menggunakan:

1. Uji validitas, yaitu suatu ukuran yang menunjukkan tingkat keabsahan dan kevalidan suatu alat ukur atau instrumen penelitian.

2. Uji realibilitas, indeks yang menunjukkan sejauh mana suatu pengukuran tanpa bias (bebas kesalahan) dan karena itu menjamin pengukuran yang konsisten lintas waktu dan lintas beragam item dalam instrumen (Sekaran, 2010).

3. Analisis regresi linier berganda, digunakan untuk mengetahui besarnya pengaruh kompetensi dan independensi auditor terhadap kualitas audit

4. Pengujian secara parsial (uji t), digunakan untuk menguji hipotesis secara parsial guna menunjukkan pengaruh tiap variabel independen secara individu terhadap variabel dependen.

5. Pengujian secara simultan (uji f) merupakan pengujian hubungan regresi secara simultan yang bertujuan untuk mengetahui apakah seluruh variabel independen bersama-sama mempunyai pengaruh yang signifikan terhadap variabel dependen.

\section{Hasil dan Diskusi}

4.1. Statistik Deskriptif

Tabel 4.1. (tersaji di Lampiran 2) menggambarkan statistik deskriptif 
variabel-variabel

independensi dan profesionalisme.

Sedangkan kualitas audit sebagai variabel dependen. Tabel 4.1 Menginformasikan variabel kompetensi menunjukan rata-rata empiris sebesar 46,23 yang berada diatas rata-rata teoritisnya yaitu 33 . Hal ini menunjukan subyek penelitian secara umum telah menunjukan adanya kompetensi yang relative besar dari auditor selama melakukan auditing. Pada variabel independensi menunjukan nilai rata-rata sebesar 51,10 yang berada diatas ratarata teoritisnya yaitu 39. Nilai rata-rata empiris tersebut menunjukan bahwa secara rata-rata subyek penelitian ini memiliki sikap independensi yang baik sebagai auditor. Variabel profesionalisme menunjukan nilai ratarata sebesar 21,15 yang berada diatas rata-rata teoritisnya yaitu 15 . Rata-rata empiris tersebut menunjukan bahwa secara rata-rata subyek penelitian ini memiliki profesionalisme yang baik sebagai auditor. Lalu variabel kualitas audit dari auditor dengan penilaian diri auditor menunjukan secara rata-rata diperoleh nilai sebesar 21,33 yang berada diatas rata-rata teoritisnya yaitu sebesar 15. Nilai rata-rata yang berada diatas 15 tersebut menunjukan adanya penilaian dari subyek bahwa mereka dapat memberikan audit yang berkualitas.

\subsection{Analisis Data}

\subsubsection{Uji Validitas dan Reliabilitas}

Validitas menunjukkan sejauh mana alat pengukur yang mana dipergunakan untuk mengukur apa yang diukur. Adapun caranya adalah dengan mengkorelasikan antara skor yang diperoleh pada masing-masing item pertanyaan dengan skor total individu.

Tabel 4.2 (tersaji di Lampiran 3) menunjukkan bahwa semua indikator yang digunakan untuk mengukur semua variabel dalam penelitian ini dinyatakan sebagai item yang valid. Diperoleh bahwa dari indikator-indikator variabel yang digunakan dalam penelitian ini semuanya memiliki nilai korelasi yang lebih besar dari 0,168 yaitu $r$ tabel untuk sampel sebanyak 97.

Uji reliabilitas merupakan suatu ukuran kestabilan dan konsistensi responden dalam menjawab hal yang berkaitan dengan pertanyaan yang merupakan suatu variabel dan disusun dalam satu bentuk kuesioner. Uji reliabilitas dapat dilakukan bersamasama terhadap seluruh nutir pertanyaan untuk lebih dari satu variabel. Pada penelitian ini pengujian realibilitas hanya dilakukan terhadap 97 responden. Pengambilan keputusan berdasarkan jika nilai Alpha melebihi 0,6 maka pertanyaan variabel tersebut reliabel dan sebaliknya (Imam Ghozali,2005:41-42). Adapun hasil dari pengujian reliabilitas adalah sebagai berikut

Berdasarkan tabel 4.3 (tersaji di Lampiran 4) terlihat bahwa variabel Kompetensi, independensi dan Kualitas Audit memiliki status reliabel. Hal ini dikarenakan nilai Alpha Cronbach variabel tersebut lebih besar dari 0,6. Kondisi ini juga memberikan arti bahwa seluruh variabel tersebut dapat digunakan pada analisis selanjutnya.

\subsubsection{Hasil Pengujian Asumsi Klasik}

1. Uji Normalitas

Uji normalitas dilakukan untuk mengetahui apakah data yang digunakan memiliki distribusi normal. Pengujian normalitas dilakukan dengan menggunakan P-P Plot Test. Pengujian normalitas dapat dideteksi dengan melihat penyebaran data (titik) pada sumbu diagonal dari grafik distribusi normal, dan hasilnya dapat dilihat pada Gambar 4.1 (tersaji di Lampiran 10). berikut : 
Berdasarkan hasil uji normalitas, dapat dilihat dari Gambar 4.1 (Normal P-Plot of Regression Standardized Residual) terlihat bahwa titik-titik menyebar di sekitar garis diagonal, serta penyebarannya mengikuti garis diagonal. Jika titik dalam gambar menyebar di sekitar garis diagonal dan arahnya mengikuti garis diagonal, hal ini menunjukan bahwa model regresi layak dipakai karena memenuhi asumsi normalitas atas data berdistribusi normal.

\section{Uji Multikolinearlitas}

Uji Multikolonieritas bertujuan untuk menguji apakah model regresi ditemukan adanya korelasi antar variabel bebas (Ghozali, 2011). Model regresi yang baik seharusnya tidak terjadi korelasi antar variabel independen. Cara untuk mengetahui akankah terjadi multikolonieritas atau tidak yaitu dengan melihat nilai Tolerance dan Variance Infkation Factor (VIF). Kedua ukuran ini menunjukan setiap variabel independen manakah yang dijelaskan oleh variabel independen lainnya. Dalam pengertian sederhana setiap variabel independen menjadi variabel dependen (terikat) dan diregresi terhadap variabel independen lainnya. Tolerance mengukur variabilitas-variabel independen yang terpilih yang tidak dijelaskan oleh variabel independen lainnya. Jadi nilai Tolerance yang rendah sama dengan nilai VIF tinggi (karena VIF $=1 /$ Tolerance $)$. Nilai cutoff yang umum dipakai untuk menunjukkan adanya multikolinearitas adalah nilai Tolerance $>0,10$ atau sama dengan nilai VIF $<10$. Hasil pengujian dapat di lihat pada Lampiran 5:

Dari hasil menunjukkan bahwa semua variabel bebas mempunyai nilai VIF yang berada jauh di bawah angka 10 sehingga dapat dikatakan semua konsep pengukur variabel-variabel yang digunakan tidak mengandung masalah multikolinieritas. Maka model regresi yang ada layak untuk dipakai dalam memprediksi kualitas audit.

\subsubsection{Uji Heteroskedastisitas}

Uji heteroskedastisitas digunakan untuk mengetahui apakah pada model regresi penyimpangan variabel bersifat konstan atau tidak. Salah satu cara untuk mengetahui adanya heteroskedastisitas dapat dilakukan dengan melihat ada tidaknya pola tertentu pada grafik scatterplot antara variabel dependen (terikat) dengan residualnya. Apabila grafik yang ditunjukan dengan titik-titik tersebut membentuk suatu pola tertentu, maka telah terjadi heteroskedastisitas dan apabila polanya acak serta tersebar, maka tidak terjadi heteroskedastisitas. Adapun grafik hasil uji heteroskedastisitas tersaji di Lampiran 11.

Dari grafik, terlihat titik-titik yang menyebar secara acak, tidak membentuk suatu pola tertentu yang jelas, serta tersebar baik di atas maupun di bawah angka 0 (nol) pada sumbu Y. Hal ini berarti tidak terjadi heteroskedastisitas pada model regresi, sehingga model regresi layak dipakai untuk memprediksi Y.

\subsubsection{Analisis Regresi Linear Berganda}

Analisis statistik yang digunakan dalam penelitian ini yaitu regresi linier berganda. Analisis ini digunakan untuk mengetahui besarnya pengaruh variabelvariabel bebas (independen) yaitu Kompetensi, Independensi dan Profesionalisme terhadap variabel terikat (dependen) yaitu Kualitas Audit. Besarnya pengaruh variabel independen yaitu Kompetensi, Independensi dan Profesionalisme dengan variabel dependen yaitu Kualitas Audit secara 
bersama-sama dapat dihitung melalui suatu persamaan regresi berganda.

\section{a. Persamaan Regresi}

Berdasarkan hasil penghitungan (tersaji di Lampiran 6), maka persamaan regresi yang terbentuk pada uji regresi ini adalah:

$$
\begin{gathered}
\mathrm{Y}=\mathbf{0 , 8 6 6}+\mathbf{0 , 9 1} \mathbf{X 1}+\mathbf{0 , 9 8} \mathrm{X2}+\mathbf{0 , 5 3 1} \\
\mathrm{X3}+\mathrm{e}
\end{gathered}
$$

Model tersebut dapat diinterpretasikan sebagai berikut :

1. Koefisien regresi variabel $\mathrm{X} 1$ (Kompetensi) diperoleh sebesar 0,091 dengan arah koefisien positif. Hal ini menunjukan bahwa kompetensi yang lebih tinggi dapat meningkatkan kualitas audit dalam pemeriksaan keuangan.

2. Koefisien regresi variabel X2 (Independensi) diperoleh sebesar 0,098 dengan arah koefisien positif. Hal ini menunjukan bahwa independensi yang lebih tinggi dapat meningkatkan kualitas audit dalam pemeriksaan keuangan.

3. Koefisien regresi variabel X3 (Profesionalisme) diperoleh sebesar 0,531 dengan arah koefisien positif. Hal ini menunjukan bahwa profesionalisme yang lebih tinggi dapat meningkatkan kualitas audit dalam pemeriksaan keuangan.

\subsubsection{Pengujian Hipotesis}

\section{Analisis Koefisien Determinasi}

Berdasarkan hasil pengujian koefesien determinasi (tersedia di Lampiran 7), menunjukkan bahwa nilai Adjusted $R^{2}$ sebesar 0,332 yang berarti bahwa variabilitas variabel dependen yaitu kualitas audit yang dapat dijelaskan oleh variabel independen yaitu variabel kompetensi, independensi dan profesionalisme auditor dalam penelitian ini adalah sebesar 32,2\%, sedangkan sisanya sebesar $67,8 \%$ dijelaskan oleh variabel-variabel lain di luar model penelitian.

\section{Pengujian Hipotesis Secara Simultan (Uji Statistik F) \\ Pengujian Hipotesis Secara} Simultan (Uji Statistik F) dimaksudkan untuk mngertahui pengaruh variabelvariabel independen yaitu kompetensi dan independensi secara simultan (bersama-sama). Hasil pengujian model keseluruhan diperoleh nilai $\mathrm{F}$ sebesar 16,931 dengan probabilitas signifikansi sebesar $0,000<0,05$. Selain itu dapat dilihat juga dari hasil perbandingan antara $F_{\text {hitung }}$ dan $F_{\text {tabel }}$ yang menunjukan nilai $F_{\text {hitung }}$ sebesar 16,931 sedangkan $F_{\text {tabel }}$ sebesar 3,09. Dengan demikian artinya bahwa variabel Kompetensi, Independensi dan Profesionalisme secara bersama-sama berpengaruh secara signifikan terhadap kualitas audit.

\section{Pengujian Hipotesis Secara Parsi al (Uji Statistik t)}

Uji $t$ (t-test) ini dimaksudkan untuk mengetahui pengaruh secara parsial (individu) variabel-variabel independen yaitu Kompetensi, Independensi dan Kompetensi terhadap variabel dependen yaitu kualitas audit atau menguji signifikansi konstanta dan variabel dependen.

a. Berdasarkan hasil uji $\mathrm{t}$ (parsial) pada model regresi, diperoleh nilai signifikansi variabel kompetensi auditor sebesar 0,092 <0,05 taraf nyata signifikansi tersebut 0,05 untuk hipotesis 2 arah sedangkan hipotesis yang peneliti ajukan adalah hipotesis 1 arah. Karena itu dapat dilihat juga dari hasil perbandingan antara $t_{\text {hitung }}$ dan $t_{\text {tabel }}$ yang menunjukan nilai $t_{\text {hitung }}$ sebesar 1.703, sedangkan $t_{\text {tabel }}$ sebesar 1.661 (hipotesis 1 arah). Dari hasil tersebut terlihat bahwa $\mathrm{t}_{\text {hitung }}>\mathrm{t}_{\text {tabel }}$ yaitu $1,703>1,661$, 
maka dapat disimpulkan bahwa $\mathrm{H}_{1}$ diterima, artinya secara parsial variabel kompetensi auditor berpengaruh secara signifikan terhadap variabel kualitas audit.

b. Berdasarkan hasil uji $\mathrm{t}$ (parsial) pada model regresi, diperoleh nilai signifikansi variabel independensi auditor sebesar $0,070<0,05$ taraf nyata signifikansi tersebut 0,05 untuk hipotesis 2 arah sedangkan hipotesis yang peneliti ajukan adalah hipotesis 1 arah. Karena itu dapat dilihat juga dari hasil perbandingan antara $t_{\text {hitung }}$ dan $t_{\text {tabel }}$ yang menunjukan nilai thitung sebesar 1,834, sedangkan $t_{\text {tabel }}$ sebesar 1,661 (hipotesis 1 arah). Dari hasil tersebut terlihat bahwa $t_{\text {hitung }}>\mathrm{t}_{\text {tabel }}$ yaitu $1,834>1,661$, maka dapat disimpulkan bahwa $\mathrm{H}_{2}$ diterima artinya secara parsial variabel independensi auditor berpengaruh secara signifikan terhadap variabel kualitas audit.

c. Berdasarkan hasil uji $\mathrm{t}$ (parsial) pada model regresi, diperoleh nilai signifikansi variabel independensi auditor sebesar $0,000<0,05$. Selain itu dapat dilihat juga dari hasil perbandingan antara thitung dan $t_{\text {tabel }}$ yang menunjukan nilai $t_{\text {hitung }}$ sebesar 6,175 , sedangkan $t_{\text {tabel }}$ sebesar 1,661 (hipotesis 1 arah). Dari hasil tersebut terlihat bahwa thitung $>\mathrm{t}_{\text {tabel }}$ yaitu $6,175>$ 1,661, maka dapat disimpulkan bahwa $\mathrm{H}_{3}$ diterima artinya secara parsial variabel profesionalisme auditor berpengaruh secara signifikan terhadap variabel kualitas audit.

Berdasarkan hasil pengujian secara parsial dilihat dari thitung $>t_{\text {tabel }}$, maka dapat disimpulkan bahwa ketiga variabel yaitu variabel kompetensi, independensi dan profesionalisme auditor masing-masing memiliki pengaruh secara signifikan terhadap variabel dependen yaitu kualitas audit.

\subsection{Interpretasi Hasil Penelitian 4.3.1. Kompetensi Auditor dan Independensi Auditor Terhadap Kualitas Audit}

Kompetensi dalam praktik akuntan publik menyangkut masalah kualitas teknis dari anggota dan stafnya serta kemampuan untuk mengawasi dan menilai mutu tugas yang telah dikerjakan. Sedangkan independensi berarti adanya kejujuran dalam diri akuntan dalam mempertimbangkan fakta-fakta dan adanya pertimbangan yang objektif, tidak memihak dalam diri akuntan dalam merumuskan dan mengungkapkan pendapatnya. Lalu profesionalisme bagaimana seorang auditor mampu mengaplikasikan kemahirannya dengan cermat dan seksama pada saat penugasan. Dengan begitu, setiap auditor memerlukan ketiganya. Karena apabila auditor hanya memiliki kompetensi dan tidak memiliki independensi atau profesionalisme yang tinggi, maka dalam melaksanakan auditnya auditor tidak dapat menghasilkan kualitas audit yang baik. Hal itu dikarenakan apabila hanya memiliki kompetensi yang baik tetapi mudah dipengaruhi oleh pihak lain maka auditor bisa memanipulasi hasil auditnya dengan kemampuan yang dimilikinya atau tidak menerapkan kemahirannya pada saat penugasan. Sedangkan apabila hanya memiliki independensi yang tinggi tetapi kurang memiliki kompetensi dan profesionalisme maka auditor akan sulit dalam melaksanakan audit dan mencari masalah yang dihadapi karena kurangnya pemahaman mengenai proses audit, baik dalam bidang auditnya sendiri ataupun dalam bidang akuntansi.

Berdasarkan hasil pengujian di atas dapat disimpulkan bahwa secara 
simultan atau bersama-sama variabel kompetensi, independensi dan profesionalisme auditor berpengaruh secara signifikan terhadap variabel dependen yaitu variabel kualitas audit. Dengan sikap kompetensi, independensi dan profesionalisme yang baik yang dimiliki auditor, maka hal tersebut akan menunjang auditor dalam mengahasilkan kualitas audit yang baik.

\subsubsection{Pengaruh Kompetensi Auditor Terhadap Kualitas Audit}

Penelitian ini menunjukan hasil bahwa terdapat pengaruh yang signifikan antara variabel kompetensi auditor terhadap kualitas audit. Kompetensi auditor merupakan salah satu yang harus dimiliki oleh seorang auditor, karena kompetensi erat kaitannya dengan kualitas audit. Dengan adanya kompetensi maka auditor dirasa memiliki pengetahuan dan pengalaman yang cukup mengenai bidang audit. Pengetahuan yang sudah dimiliki harus digali lebih banyak lagi sehingga dapat memudahkan auditor dalam memecahkan permasalahan yang dihadapi saat melaksanakan proses audit dan dapat mengikuti perkembangan yang terjadi saat ini. Pengalaman yang pernah didapat sebelumnya harus dituangkan kembali saat melakukan proses audit, sehingga dalam menyelesaikan proses audit akan lebih baik dan lebih cepat karena sudah pempunyai pengalaman sebelumnya. Dengan pengetahuan dan pengalaman dalam bidang audit, maka auditor akan dapat menyelesaikan auditnya dengan baik sehingga mampu menghasilkan kualitas audit yang baik dan memadai.

Hasil penelitian ini ini didukung oleh hasil penelitian sebelumnya yaitu penelitian yang dilakukan oleh Tjun et al (2012), Ilmiyati dan Suhardjo (2012) dan Sari (2012) yang menunjukan hasil bahwa kompetensi auditor berpengaruh terhadap kualitas audit.

\subsubsection{Pengaruh Independensi Auditor Terhadap Kualitas Audit}

Hasil penelitian ini ini bertolak belakang dengan hasil penelitian sebelumnya yaitu penelitian yang dilakukan oleh Tjun et al (2012) yang menunjukan hasil bahwa independensi auditor tidak berpengaruh terhadap kualitas audit. Namun hasil penelitian ini didukung oleh hasil penelitian yang dilakukan oleh peneliti sebelumnya yaitu oleh Singgih, Muliani dan Bawono (2010), Harhinto dan Teguh (2004), Indah (2010) dan Sari (2012) yang menunjukan hasil bahwa independensi auditor berpengaruh terhadap kualitas audit.

Namun hasil penelitian ini sejalan dengan logika teori pada pembahasan sebelumnya bahwa independensi merupakan sikap yang diharapkan dari seorang akuntan publik untuk tidak mempunyai kepentingan pribadi dalam melaksanakan tugasnya, karena hal itu bertentangan dengan prinsip integritas dan objektivitas. Oleh karena itu, cukuplah beralasan bahwa untuk menghasilkan audit yang berkualitas diperlukan sikap independen dari auditor. Karena jika auditor kehilangan independensinya maka laporan audit yang dihasilkan tidak sesuai dengan kenyataan yang ada sehingga tidak dapat digunakan sebagai dasar pengambilan keputusan. Kemudian dengan sikap independensinya maka auditor dapat melaporkan dalam laporan auditan jika terjadi pelanggaran dalam laporan keuangan kliennya. Sehingga berdasarkan uraian tersebut, dapat disimpulkan bahwa semakin tinggi independensi yang dimiliki auditor maka semakin tinggi pula kualitas audit yang dihasilkan.

Alim et al. (2007) dan Christiawan 
(2002) menemukan bahwa independensi berpengaruh signifikan terhadap kualitas audit. Auditor harus dapat mengumpulkan setiap informasi yang dibutuhkan dalam pengambilan keputusan audit di mana hal tersebut harus didukung dengan sikap independen.

Berdasarkan hasil penelitian ini yang menunjukan bahwa terdapat pengaruh yang signifikan antara independensi auditor terhadap kualitas auditor. Dengan adanya sikap independensi tinggi yang dimiliki oleh auditor, maka auditor dalam melakukan proses audit, auditor akan bersikap objektif dalam memeriksa tanpa memandang siapapun subjek atau klien yang sedang diaudit. Sikap independensi diperlukan oleh seorang auditor, agar dalam memeriksa juga auditor tidak dibatasi ruang lingkupnya, sehingga auditor dapat memeriksa secara leluasa. Dengan adanya independensi juga, auditor tidak akan terpengaruh oleh siapapun ketika melakukan pemeriksaan.

\subsubsection{Pengaruh Profesionalisme Audi- tor Terhadap Kualitas Audit}

Hasil penelitian ini sejalan dengan penelitian yang dilakukan oleh Dian Ika Sulistiyowati (2010), yang menemukan bahwa Profesionalisme Auditor Internal berpengaruh positif dan signifikan terhadap Kualitas Audit. Dalam penelitian tersebut mengungkapkan bahwa profesionalisme auditor merupakan salah satu faktor yang penting untuk menghasilkan audit yang berkualitas, karena jika auditor tidak professional dalam menjalankan profesinya, maka laporan audit yang dihasilkan tidak sesuai dengan kenyataan yang ada sehingga tidak dapat digunakan sebagai dasar pengambilan keputusan.

\section{Penutup}

\subsection{Simpulan}

Penelitian ini meneliti tentang pengaruh kompetensi dan independensi auditor terhadap kualitas audit. Variabel penelitian yang digunakan adalah variabel dependen, yaitu kualitas audit. Sedangkan variabel independen yang digunakan adalah kompetensi dan independensi auditor. Analisis dilakukan dengan menggunakan Analisis Regresi Linear Berganda dengan program Statistical Package for Sosial Sciences (SPSS) Ver. 21.00. Subjek penelitian ini adalah 18 Kantor Akuntan Publik di Jakarta Selatan dengan jumlah responden sebanyak 97 responden.

Berdasarkan hasil pengujian hipotesis dan mengacu pada perumusan serta tujuan dari penelitian ini, maka dapat ditarik kesimpulan-kesimpulan sebagai berikut :

1. Kompetensi auditor dalam melaksanakan audit berpengaruh positif dan signifikan terhadap kualitas audit pada Kantor Akuntan Publik di Jakarta Selatan, sehingga semakin berkompeten seorang auditor maka akan semakin baik kualitas audit yang dilakukannya.

2. Independensi auditor dalam melaksanakan audit berpengaruh positif dan signifikan terhadap kualitas audit pada Kantor Akuntan Publik di Jakarta Selatan, sehingga semakin tinggi sikap independensi seorang auditor maka akan semakin tinggi pula kualitas audit yang dihasilkannya.

3. Profesionalisme auditor dalam melaksanakan audit berpengaruh positif dan signifikan terhadap kualitas audit pada Kantor Akuntan Publik di Jakarta Selatan, sehingga semakin tinggi profesionalisme seorang auditor maka akan semakin tinggi pula kualitas audit yang dihasilkannya. 


\subsection{Saran}

Berdasarkan hasil penelitian pada beberapa Kantor Akuntan Publik di Jakarta Selatan, peneliti mengajukan beberapa saran sebagai lahan masukan dan pertimbangan yang diharapkan dapat meningkatkan Kompetensi dan Independensi Auditor dalam pengembangan ilmu pengetahuan di bidang ekonomi akuntansi pada umumnya dan khususnya mengenai auditing, diantaranya adalah sebagai berikut :

1. Bagi Auditor di Kantor Akuntan Publik yang menjadi subjek dalam penelitian ini:

Berdasarkan hasil penelitian menunjukan adanya pengaruh yang signifikan dari variabel kompetensi, independensi dan profesionalisme auditor terhadap kualitas audit. Berdasarkan hasil tersebut, diharapkan auditor di Kantor Akuntan Publik di Jakarta Selatan agar dapat mempertahankan kompetensi, independensi dan profesionalisme sehingga dapat menunjang kualitas audit yang dihasilkan.

2. Bagi peneliti selanjutnya

a. Diharapkan untuk peneliti selanjutnya tidak terpaku pada ketiga faktor dalam penelitian ini yaitu kompetensi, independensi dan profesionalisme auditor, namun dapat menambah faktor-faktor lain yang mungkin dapat mempengaruhi kualitas audit dan melakukan penyebaran kuesioner pada bulan Oktober sampai Desember dikarenakan pada bulan Januari hingga April merupakan periode yang sangat sibuk untuk para auditor . b. Agar hasil penelitian ini dapat digunakan secara luas, maka untuk peneliti berikutnya subjek penelitian diharapkan tidak hanya terbatas pada Kantor Akuntan Publik di Jakarta Selatan saja.

Perlu diketahui pula penilitian ini terbatas pada objek penelitian profesi auditor yang bekerja dalam Kantor Akuntan Publik (KAP) di Jakarta selatan. Sehingga dimungkinkan adanya perbedaan hasil, pembahasan ataupun kesimpulan untuk objek penelitian yang berbeda. Dan penyebaran kuesioner ini dilakukan pada Bulan Januari hingga Februari sehingga pada bulan-bulan tersebut auditor sedang dalam kesibukan yang sangatn padat.

\section{Daftar Pustaka}

Alim, M.N.; Hapsari, T.; dan Purwanti, L. Pengaruh Kompetensi dan Independensi terhadap Kualitas Audit dengan Etika Auditor Sebagai Variabel Moderasi. Simposium Nasional Akuntansi $X$. Unhas Makassar, 2628 Juli 2007.

Agoes, Sukrisno. (2008). Auditing: (Pem eriksaan Akuntan) oleh Kantor A kuntan Publik Jilid I. Edisi ketiga. Jakarta: Lembaga Penerbit Fakultas Ekonomi Universitas Indonesia.

Arens, Alvin A., Randal J. Elder, dan Beasley Mark S . 2012. Auditing and Assurances Services And Integrated Approach .Edisi Kedua belas. Prentice Hall.

Christiawan, Yulius Jogi. 2002. Kompetensi dan Independensi Akuntan Publik: Refleksi Hasil Penelitian Empiris. Jurnal Akuntansi dan Keuangan. Vol. 4 No.2 (Nov) hal. 79-92. 
Djamil, Nasrullah 2011. Faktor-Faktor yang Mempengaruhi Kualitas Audit Pada Sektor Publik dan Beberapa Karakteristik Untuk Meningkatkannya. Riau. (http://nasrullahdjamiluin.blogspot.com/2011/03/faktorfaktor-yang-mempengaruhi.html) Diakses tanggal 18 September 2015.

De Angelo, Linda Elizabeth. 1981. "Auditor Size and Audit Quality". Journal of Accounting \& Economics.

Deis, Donald L. Dan Gari A. Giroux. 1992. "Determinants of Audit Quality In The Public Sector". The Accounting Review Vol. 67 No.3 (Juli). Pp.462479.

Elfarini, Eunike Christina. 2007. Pengaruh Kompetensi dan Independensi Auditor terhadap Kualitas Audit. Penelitian. Universitas Negeri Semarang.

Harhinto, Teguh. 2004. Pengaruh Keahlian dan Independensi Terhadap Kualitas Audit Studi Empiris Pada KAP di Jawa Timur. Semarang.Tesis Maksi : Universitas Diponegoro.

Institut Akuntan Publik Indonesia. 2011. Standar Profesi Akuntan Publik. Jakarta : Salemba Empat.

Ilmiyati dan Suhardjo. 2012. Pengaruh Akuntabilitas dan Kompetensi Auditor Terhadap Kualitas Audit. Jurnal Akuntansi. Vol 1 No.1 (Januari).

Indah, Siti NurMawar. 2010. "Pengaruh Kompetensi dan Independensi Auditor Terhadap Kualitas Audit (Studi Empiris Pada Auditor KAP di Semarang)". Skripsi Program Sarjana Fakultas Ekonomi Universitas Diponegoro.

Kasidi.2007."Faktor-Faktor yang Mempengaruhi Independensi
Auditor (Persepsi Manajer Keuangan Perusahaan Manufaktur di Jawa Tengah)". Tesis Program Studi Magister Sains Akuntansi Universitas Diponogoro.

Kusharyanti. 2003. "Temuan penelitian mengenai kualitas audit dan kemungkinan topik penelitian di masa datang". Jurnal Akuntansi dan Manajemen (Desember). Hal.25-60

Libby, R., D. Frederick. 1990. "Experience and the ability to explain audit findings. "Journal of Accounting Research 28: 348367.

Mautz, R. K. dan H. A. Sharaf. 1961. The Philosophy of Auditing. Sarasota, Florida: American Accounting Association.

Menteri Keuangan Republik Indonesia. 2008. Peraturan Menteri Keuangan Republik Indonesia Nomor 17/PMK.01/2008 tentang Jasa Akuntan Publik.Jakarta.

Mulyadi. 2010.Auditing. Edisi Keenam. Buku 1. Jakarta: Salemba Empat.

Peraturan Menteri Keuangan Republik Indonesia Nomor: 17/PMK.01/2008 (PMKRI) 2008. Tentang Jasa Akuntan Publik.

Pusat Pembinaan Akuntan dan Jasa Penilai (PPAJP), KEMENKEU RI.

Putri, Yowinna juanita. 2015. "Pengaruh Kompetensi, Independensi, Profesionalisme dan Akuntabilitas Terhadap Kualitas Audit Dengan Etika Auditor Sebagai Variabel Moderasi". Skripsi Program Sarjana Fakultas Ekonomi Universitas Multimedia Nusantara. 
Rai, I Gusti Agung. 2010.Audit Kinerja pada Sektor Publik. Jakarta: Salemba Empat

Restu Agustin dan Nastia Putri Pertiwi. (2013). Pengaruh Kompetensi, Independensi dan Profesionalisme Terhadap Kualitas Audit (Studi Empiris Pada Kantor Akuntan Publik Se Sumatera). Jurnal Ekonomi. Vol.21 No.3 (Sep) Hal.1-13.

Saktiyanto, Heri, dkk. 2013. Expectancy Theory. Bogor: MB-IPB.

Sari, Rosalina. 2012. Pengaruh Kompetensi dan Independensi Terhadap Kualitas Audit. Jurnal Akuntansi. Vol.1 No.2 (Februari).

Singgih, Elisha Muliani dan Icuk Rangga Bawono. 2010. Pengaruh Independensi, Pengalaman, Due Proffesional Care, dan Akuntanbilitas terhadap Kualitas Audit. Simposium Nasional Akuntansi XIII. Purwokerto

Surat Keputusan Ketua Umum Institut Akuntan Publik Indonesia tanggal 2 Juli 2008 SK KEP.024/IAPI/VII/2008 tentang "Kebijakan Penentuan Fee".

Suryaningtias, Agustin. 2007. "Faktorfaktor yang Mempengaruhi
Independensi Akuntan Publik (Studi Survei Pada Kantor Akuntan Publik di Bandung)". Skripsi Program Sarjana Fakultas Ekonomi Universitas Widyatama.

Tjun, Law Tjun Elyzabet Indrawati Marpaung dan Santy Setiawan. 2012. Pengaruh Kompetensi dan Independensi Auditor Terhadap Kualitas Audit. Jurnal Akuntansi. Vol.4 No.1 (Mei).

Tuanakotta, Theodorus M. 2011. Berpikir Kritis dalam Auditing. Jakarta: Salemba Empat

Undang-Undang Republik Indonesia No. 5 Tahun 2011 tentang "AkuntanPublik".

Wooten, T.G. 2003. It is Imposible to Know The Number of PoorQuality Auditsthat simply go undetected and unpublicized. The CPA Journal, Januari. P.48-51

Yuvisa, Rohaman, Handayani 2008. Pengaruh Identifikasi Auditor atas Klien Terhadap Objektivitas Auditor dengan Auditor Tenure, Client Importancedan Client Image sebagai Variabel anteseden.penelitian. Universitas Panca Marga-Probolinggo. 


\section{Apendix \\ Lampiran 1 \\ Prosedur Penelitian \\ FAKTOR KOMPETENSI, INDEPENDENSI DAN PROFESIONALISME AUDITOR TERHADAP KUALITAS AUDIT}

1. Nama kantor Akuntan Publik

2. Jabatan/ posisi Anda pada KAP saat ini
a. Partner
c. Junior Auditor
b. Senior Auditor
d. Lain-lain (sebutkan)

3. Lama pengalaman kerja di bidang audit sampai saat ini :

_tahun _ bulan

4. Keahlian khusus yang Anda miliki saat ini disamping audit
a. Analisis system
c. Konsultan manajemen
b. Konsultan pajak
d. Lain-lain (sebutkan)

5. Lama Anda menekuni keahlian tersebut : tahun

6. Tingkat Pendidikan formal Anda
a. Pendidikan Pra Sarjana (setingkat D3, jika ada)

Program/bidang studi (akuntansi, manajemen, dll)

b. Pendidikan Sarjana (S1), gelar (missal : Drs, SE, dll)

Program/bidang studi (akuntansi, manajemen, dll)

c. Pendidikan Strata (S2), gelar (missal : MSi, MM, dll)

Program/bidang studi(akuntansi, manajemen, dll)

d. Pendidikan Strata (S3)

Program/bidang studi(akuntansi, manajemen, dll)

7. Apakah Anda mempunyai sertifikat/gelar professional lain yang menunjang bidang keahlian (selain akuntan publik)
a. Ya, sebutkan
b. Tidak

\section{Pertanyaan Mengenai Pendapat Auditor}

Bapak/Ibu/Sdr/i dimohon untuk memberikan tanggapan yang sesuai atas pertanyaanpertanyaan berikut dengan memilih skor yang tersedia dengan cara disilang (x). Jika menurut Bapak/Ibu/Sdr/i tidak ada jawaban yang tepat, maka jawaban dapat diberikan pada pilihan yang paling mendekati. Skor jawaban dapat diberikan pada pilihan yang paling mendekati. Skor jawaban adalah sebagai berikut :

Skor 1 : Sangat Tidak Setuju (STS)

Skor 2 : Tidak Setuju (TS)

Skor 3 : Netral (N)

Skor 4 : Setuju (S)

Skor 5 : Sangat Setuju (SS)

\begin{tabular}{|c|c|c|c|c|c|c|}
\hline No & Pernyataan & STS & TS & $\mathrm{N}$ & $\mathrm{S}$ & $\mathrm{SS}$ \\
\hline \multicolumn{7}{|c|}{ Pengetahuan } \\
\hline 1. & $\begin{array}{l}\text { Setiap akuntan publik harus memahami dan } \\
\text { melaksanakan jasa profesionalnya sesuai dengan } \\
\text { Standar Akuntansi Keuangan (SAK) dan Standar } \\
\text { Profesional Akuntan Publik (SPAP) yang relevan. }\end{array}$ & 1 & 2 & 3 & 4 & 5 \\
\hline 2. & Untuk melakukan audit yang baik, saya perlu & 1 & 2 & 3 & 4 & 5 \\
\hline
\end{tabular}




\begin{tabular}{|c|l|l|l|l|l|l|}
\hline & memahami jenis industri klien. & & & & \\
\hline 3. & $\begin{array}{l}\text { Untuk melakukan audit yang baik, saya perlu } \\
\text { memahami kondisi perusahaan klien. }\end{array}$ & 2 & 3 & 4 & 5 \\
\hline 4. & $\begin{array}{l}\text { Untuk melakukan audit yang baik, saya } \\
\text { membutuhkan pengetahuan yang diperoleh dari } \\
\text { tingkat pendidikan formal. }\end{array}$ & 1 & 3 & 4 & 5 \\
\hline
\end{tabular}

\section{Keahlian Khusus}

5. Saya mengikuti beberapa pelatihan sehingga kemampuan audit saya lebih meningkat seperti komputerisasi, wawancara dsb.

6. Selain pendidikan formal, untuk melakukan audit yang baik, saya juga membutuhkan pengetahuan yang diperoleh dari kursus dan pelatihan khususnya di bidang audit.

7. Keahlian khusus yang saya miliki dapat mendukung proses audit yang saya lakukan.

\section{Pengalaman}

\begin{tabular}{|c|l|c|c|c|c|c|}
\hline No & \multicolumn{1}{|c|}{ Pernyataan } & STS & TS & N & S & SS \\
\hline 9. & $\begin{array}{l}\text { Saya telah memiliki banyak pengalaman dalam } \\
\text { bidang audit dengan berbagai macam klien } \\
\text { sehingga audit yang saya lakukan menjadi lebih } \\
\text { baik. }\end{array}$ & 1 & 2 & 3 & 4 & 5 \\
\hline 10. & $\begin{array}{l}\text { Walaupun sekarang jumlah klien saya banyak, audit } \\
\text { yang saya lakukan belum tentu lebih baik dari } \\
\text { sebelumnya. }\end{array}$ & 2 & 3 & 4 & 5 \\
\hline 11. & $\begin{array}{l}\text { Saya pernah mengaudit perusahaan yang go public, } \\
\text { sehingga saya dapat mengaudit perusahaan yang } \\
\text { belum go public lebih baik. }\end{array}$ & 2 & 3 & 4 & 5 \\
\hline 8. & $\begin{array}{l}\text { Semakin banyak jumlah klien yang saya audit akan } \\
\text { memberikan nilai tambah untuk saya mengenai } \\
\text { pengalaman mengaudit. }\end{array}$ & 1 & 2 & 3 & 4 & 5 \\
\hline
\end{tabular}

\section{Hubungan Dengan Klien}

12. Auditor sebaiknya memiliki hubungan dengan klien yang sama paling lama 3 tahun.

13. Saya berupaya tetap bersifat independen dalam melakukan audit walaupun telah lama menjalin hubungan dengan klien.

14. Tidak semua kesalahan klien yang saya temukan saya laporkan meskipun saya mempunyai hubungan cukup lama dengan klien.

\begin{tabular}{|l|l|l|l|l|}
1 & 2 & 3 & 4 & 5 \\
\hline 1 & 2 & 3 & 4 & 5 \\
1 & 2 & 3 & 4 & 5 \\
\hline
\end{tabular}

Tekanan Dari Klien 


\begin{tabular}{|c|l|l|l|l|l|l|}
\hline 15. & $\begin{array}{l}\text { Agar tidak kehilangan klien, kadang-kadang saya } \\
\text { harus bertindak tidak jujur. }\end{array}$ & 1 & 3 & 4 & 5 \\
\hline 16. & $\begin{array}{l}\text { Jika audit yang saya lakukan buruk, maka saya } \\
\text { dapat menerima sanksi dari klien. }\end{array}$ & 1 & 2 & 3 & 4 & 5 \\
\hline 17. & $\begin{array}{l}\text { Tidak semua kesalahan klien saya laporkan, karena saya } \\
\text { telah mendapat peringatan dari klien. }\end{array}$ & 1 & 2 & 3 & 4 & 5 \\
\hline 18. & $\begin{array}{l}\text { Saya tidak berani melaporkan kesalahan klien karena klien } \\
\text { dapat mengganti posisi saya dengan mudah }\end{array}$ & 1 & 2 & 3 & 4 & 5 \\
\hline 19. & $\begin{array}{l}\text { Jika audit fee dari satu klien merupakan sebagian } \\
\text { besar dari total pendapatan suatu kantor akuntan } \\
\text { maka hal ini dapat merusak independensi akuntan } \\
\text { publik. }\end{array}$ & 1 & 2 & 3 & 4 & 5 \\
\hline 20 & $\begin{array}{l}\text { Fasilitas yang saya terima dari klien menjadikan } \\
\text { saya sungkan terhadap klien sehingga kurang bebas } \\
\text { dalam melakukan audit. }\end{array}$ & 1 & 2 & 3 & 4 & 5 \\
\hline
\end{tabular}

\section{Telaah dari Rekan Auditor}

\begin{tabular}{|l|l|c|c|c|c|c|}
\hline 21. & $\begin{array}{l}\text { Saya tidak membutuhkan telaah dari rekan auditor } \\
\text { untuk menilai prosedur audit yang saya lakukan, } \\
\text { karena kurang dirasa manfaatnya. }\end{array}$ & 1 & 2 & 3 & 4 & 5 \\
\hline 22. & $\begin{array}{l}\text { Saya bersikap jujur untuk menghindari penilaian } \\
\text { kurang dari rekan seprofesi (sesama auditor) dalam } \\
\text { tim. }\end{array}$ & 1 & 2 & 3 & 4 & 5 \\
\hline No & Pernyataan & STS & TS & N & S & SS \\
\hline
\end{tabular}

\section{Jasa Non Audit yang diberikan oleh KAP}

\begin{tabular}{|l|l|l|l|l|l|l|}
\hline 23. & $\begin{array}{l}\text { Jasa non audit yang diberikan pada klien dapat } \\
\text { merusak independensi penampilan akuntan publik } \\
\text { tersebut. }\end{array}$ & 1 & 2 & 3 & 4 & 5 \\
\hline 24. & $\begin{array}{l}\text { Pemberian jasa lain selain jasa audit dapat } \\
\text { meningkatkan informasi yang disajikan dalam } \\
\text { laporan pemeriksaan akuntan publik. }\end{array}$ & 1 & 2 & 3 & 4 & 5 \\
\hline
\end{tabular}

\section{Deteksi Salah Saji}

\begin{tabular}{|c|l|c|c|c|c|c|}
\hline 25. & $\begin{array}{l}\text { Saya tidak mudah percaya terhadap pernyataan klien selama } \\
\text { melakukan audit. }\end{array}$ & 1 & 2 & 3 & 4 & 5 \\
\hline 26. & $\begin{array}{l}\text { Saya selalu berusaha hati-hati dalam pengambilan keputusan } \\
\text { selama melakukan audit. }\end{array}$ & 1 & 2 & 3 & 4 & 5 \\
\hline
\end{tabular}

\section{Kesesuaian dengan SPAP}

\begin{tabular}{|l|l|l|l|l|l|l|l|}
\hline 27. & $\begin{array}{l}\text { Saya menjadikan SPAP sebagai pedoman dalam } \\
\text { melaksanakan pekerjaan lapangan. }\end{array}$ & 1 & 2 & 3 & 4 & 5 \\
\hline
\end{tabular}


Kepatuhan Terhadap Standar Operasional Perusahaan

\begin{tabular}{|c|l|c|c|c|c|c|}
\hline 28. & $\begin{array}{l}\text { Pemahaman terhadap sistem informasi akuntansi klien dapat } \\
\text { menjadikan pelaporan audit lebih baik. }\end{array}$ & 1 & 3 & 4 & 5 \\
\hline 29. & $\begin{array}{l}\text { Saya mempunyai komitmen yang kuat untuk melakukan } \\
\text { audit berdasarkan prinsip etika profesi. }\end{array}$ & 1 & 2 & 3 & 4 & 5 \\
\hline
\end{tabular}

\section{Profesionalisme Auditor}

\begin{tabular}{|c|l|c|c|c|c|c|}
\hline 30. & $\begin{array}{l}\text { Saya menggunakan segenap pengetahuan, kemampuan dan } \\
\text { pengalaman saya dalam melaksanakan proses pengauditan. }\end{array}$ & 1 & 2 & 3 & 4 & 5 \\
\hline 31. & $\begin{array}{l}\text { Sebagai seorang auditor saya harus menyampaikan hasil } \\
\text { audit dengan sebenar-benarnya. }\end{array}$ & 1 & 2 & 3 & 4 & 5 \\
\hline 32. & $\begin{array}{l}\text { Profesi auditor merupakan profesi yang dapat dijadikan dasar } \\
\text { kepercayaan bagi pihak terhadap laporan keuangan yang } \\
\text { disajikan oleh manajemen. }\end{array}$ & 1 & 2 & 3 & 4 & 5 \\
\hline 33. & $\begin{array}{l}\text { Saya merencanakan dan memutuskan hasil audit saya } \\
\text { berdasarkan fakta yang saya temui dalam proses audit. }\end{array}$ & 1 & 2 & 3 & 4 & 5 \\
\hline 34. & $\begin{array}{l}\text { Sebagai seorang auditor saya harus menjalankan peraturan, } \\
\text { standar auditing, etika profesi dan pengendalian mutu. }\end{array}$ & 1 & 2 & 3 & 4 & 5 \\
\hline
\end{tabular}

Terima kasih atas kesediaan Bapak/lbu/Saudara/i mengisi kuesioner ini. Saya menjamin kerahasiaan jawaban Bapak/Ibu/Saudara/i hanya digunakan untuk kepentingan akademik semata.

\section{Distribusi Kuesioner}

\begin{tabular}{|c|l|c|c|}
\hline No & \multicolumn{1}{|c|}{ Nama KAP } & $\begin{array}{c}\text { Kuesioner } \\
\text { yang disebar }\end{array}$ & $\begin{array}{c}\text { Kuesioner yang } \\
\text { kembali }\end{array}$ \\
\hline 1 & Arman Hendiyanto \& Rekan & 5 & 5 \\
\hline 2 & Armen, Budiman \& Rekan & 5 & 5 \\
\hline 3 & Darmawan \& Hendang & $\mathbf{6}$ & $\mathbf{6}$ \\
\hline 4 & Doli, Bambang, Sulistiyanto, Dadang \& Ali & $\mathbf{1 0}$ & $\mathbf{1 0}$ \\
\hline 5 & Hadori Sugiarto Adi \& Rekan & 5 & 5 \\
\hline 6 & Indra, Sumijono \& Rekan & 11 & 10 \\
\hline 7 & Ishak, Saleh, Soewondo \& Rekan & 2 & 2 \\
\hline 8 & Kartoyo, Drs. \& Rekan & 5 & 5 \\
\hline 9 & Krisnawan, Busroni, Achsin \& Alamsyah & 12 & 10 \\
\hline 10 & Labib Y. Wardiman \& Rekan & 3 & 3 \\
\hline 11 & Morhan dan Rekan & 5 & 5 \\
\hline 12 & Nugroho \& Rekan & 5 & 5 \\
\hline 13 & Pieter, Uways \& Rekan & 5 & 5 \\
\hline 14 & Rama Wendra & 5 & 5 \\
\hline 15 & Santoso Harsokusumo, Drs., Irwan \& Rekan & 2 & 2 \\
\hline 16 & Teramihardja, Pradhono \& Chandra & 5 & 5 \\
\hline 17 & Weddie Andriyanto \& Muhaemin & 5 & 5 \\
\hline No & & Kuesioner & Kuesioner yang \\
\hline
\end{tabular}




\begin{tabular}{|c|l|c|c|}
\hline 18 & Yanuar \& Riza & 4 & 4 \\
\hline \multicolumn{2}{|c|}{ Jumlah } & 100 & 97 \\
\hline
\end{tabular}

\section{Lampiran 2}

Tabel 4.1

Statistik Deskriptif

\begin{tabular}{|l|l|l|l|}
\hline Variabel & Ukuran & Teoritis & Empiris \\
\hline Kompetensi & Minimum & $\mathbf{1 1}$ & $\mathbf{3 5}$ \\
& Maksimum & $\mathbf{5 5}$ & $\mathbf{5 5}$ \\
& Mean & $\mathbf{3 3}$ & $\mathbf{4 6 , 2 3}$ \\
\hline Independensi & Minimum & $\mathbf{1 3}$ & $\mathbf{4 3}$ \\
& Maksimum & $\mathbf{6 5}$ & $\mathbf{5 9}$ \\
& Mean & $\mathbf{3 9}$ & $\mathbf{5 1 , 1 0}$ \\
\hline Profesionalisme & Minimum & $\mathbf{5}$ & $\mathbf{1 5}$ \\
& Maksimum & $\mathbf{2 5}$ & $\mathbf{2 5}$ \\
& Mean & $\mathbf{1 5}$ & $\mathbf{2 1 , 1 5}$ \\
\hline Kualitas Audit & Minimum & $\mathbf{5}$ & $\mathbf{1 1}$ \\
& Maksimum & $\mathbf{2 5}$ & $\mathbf{2 5}$ \\
& Mean & $\mathbf{1 5}$ & $\mathbf{2 1 . 3 3}$ \\
\hline
\end{tabular}

\section{Lampiran 3}

Tabel 4.2

Hasil Pengujian Validitas

\begin{tabular}{|c|c|c|c|}
\hline Variabel / Indikator & Korelasi & $\mathrm{r}$ tabel & Keterangan \\
\hline \multicolumn{4}{|l|}{ Kompetensi (X1) } \\
\hline 1 & 0,236 & 0,168 & Valid \\
\hline 2 & 0,607 & 0,168 & Valid \\
\hline 3 & 0,653 & 0,168 & Valid \\
\hline 4 & 0,645 & 0,168 & Valid \\
\hline 5 & 0,734 & 0,168 & Valid \\
\hline 6 & 0,651 & 0,168 & Valid \\
\hline 7 & 0,679 & 0,168 & Valid \\
\hline 8 & 0,620 & 0,168 & Valid \\
\hline 9 & 0,395 & 0,168 & Valid \\
\hline 10 & 0,544 & 0,168 & Valid \\
\hline 11 & 0,511 & 0,168 & Valid \\
\hline \multicolumn{4}{|l|}{ Independensi (X2) } \\
\hline 1 & 0,506 & 0,168 & Valid \\
\hline 2 & 0,525 & 0,168 & Valid \\
\hline 3 & 0,468 & 0,168 & Valid \\
\hline 4 & 0,352 & 0,168 & Valid \\
\hline 5 & 0,291 & 0,168 & Valid \\
\hline 6 & 0,567 & 0,168 & Valid \\
\hline 7 & 0,537 & 0,168 & Valid \\
\hline 8 & 0,497 & 0,168 & Valid \\
\hline 9 & 0,527 & 0,168 & Valid \\
\hline Variabel / Indikator & Korelasi & $\mathrm{r}$ tabel & Keterangan \\
\hline 10 & 0,581 & 0,168 & Valid \\
\hline 11 & 0,600 & 0,168 & Valid \\
\hline 12 & 0,384 & 0,168 & Valid \\
\hline
\end{tabular}




\begin{tabular}{|c|c|c|c|}
\hline 13 & 0,486 & 0,168 & Valid \\
\hline Profesionalisme (X3) & & & Valid \\
\hline 1 & 0,793 & 0,168 & Valid \\
\hline 2 & 0.810 & 0,168 & Valid \\
\hline 3 & 0,789 & 0,168 & Valid \\
\hline 4 & 0,830 & 0,168 & Valid \\
\hline 5 & 0,775 & 0,168 & Valid \\
\hline Kualitas Audit (Y) & & & Valid \\
\hline 1 & 0,753 & 0,168 & Valid \\
\hline 2 & 0,773 & 0,168 & Valid \\
\hline 3 & 0,744 & 0,168 & Valid \\
\hline 4 & 0,771 & 0,168 & \\
\hline 5 & 0,806 & 0,168 & \\
\hline
\end{tabular}

Sumber : Data Primer yang diolah

\section{Lampiran 4}

Tabel 4.3

Hasil Uji Reliabilitas

\begin{tabular}{|l|c|c|}
\hline \multicolumn{1}{|c|}{ Variabel } & Nilai Alpha & Keterangan \\
\hline $\mathrm{X} 1$ (Kompetensi) & 0,787 & Reliabel \\
\hline Variabel & Nilai Alpha & Keterangan \\
\hline X2 (Independensi) & 0,711 & Reliabel \\
\hline X3 (Profesionalisme) & 0,858 & Reliabel \\
\hline Y (Kualitas Audit) & 0,828 & Reliabel \\
\hline
\end{tabular}

Sumber : Data Primer yang diolah

\section{Lampiran 5}

Tabel 4.4

Hasil Pengujian Multikolinieritas

\begin{tabular}{|ll|l|l|}
\hline \multicolumn{2}{|l|}{ Model } & \multicolumn{2}{|l|}{ Collinearity Statistics } \\
\cline { 3 - 4 } & & Tolerance & VIF \\
\hline \multirow{3}{*}{1} & (Constant) & .889 & \\
& Kompetensi & .888 & 1.125 \\
& Independensi & .994 & 1.006 \\
& Profeionalisme & & \\
\hline
\end{tabular}

Sumber : Data primer yang diolah

\section{Lampiran 6}

Tabel 4.5

Model Persamaan Regresi

Coefficients $^{\text {a }}$

\begin{tabular}{|c|c|c|c|c|c|c|c|}
\hline \multirow[t]{2}{*}{ Model } & \multicolumn{2}{|c|}{$\begin{array}{l}\text { Unstandardized } \\
\text { Coefficients }\end{array}$} & \multirow{2}{*}{$\begin{array}{l}\begin{array}{l}\text { Standardized } \\
\text { Coefficients }\end{array} \\
\text { Beta } \\
\end{array}$} & \multirow[t]{2}{*}{$\mathrm{T}$} & \multirow[t]{2}{*}{ Sig. } & \multicolumn{2}{|c|}{$\begin{array}{l}\text { Collinearity } \\
\text { Statistics }\end{array}$} \\
\hline & $\mathrm{B}$ & Std. Error & & & & Tolerance & VIF \\
\hline $1 \quad$ (Constant) & .866 & 3.411 & & .254 & .800 & & \\
\hline
\end{tabular}

JIAFE (Jurnal Ilmiah Akuntansi Fakultas Ekonomi)

Volume 2 No. 1 Tahun 2016 Edisi 2, Hal. 16-37 


\begin{tabular}{|l|l|l|l|l|l|l|l|}
\hline Kompetensi & .091 & .053 & .151 & 1.703 & .092 & .889 & 1.125 \\
Independensi & .098 & .054 & .162 & 1.834 & .070 & .888 & 1.126 \\
Profeionalisme & .531 & .086 & .517 & 6.175 & .000 & .994 & 1.006 \\
Auditor & .53 &
\end{tabular}

a. Dependent Variable: Kualitas Audit

Sumber : Data Primer yang diolah

Lampiran 7

Tabel 4.6

Koefisien Determinasi

\begin{tabular}{|l|l|l|l|l|}
\hline $\begin{array}{l}\text { Mode } \\
1\end{array}$ & $\mathrm{R}$ & $\mathrm{R}$ Square & $\begin{array}{l}\text { Adjusted R } \\
\text { Square }\end{array}$ & $\begin{array}{l}\text { Std. Error of } \\
\text { the Estimate }\end{array}$ \\
\hline 1 & $.594^{\mathrm{a}}$ & .353 & .332 & 1.944 \\
\hline
\end{tabular}

Sumber : Data primer yang diolah

\section{Lampiran 8}

Tabel 4.7

Model Pengaruh Variabel Secara Bersama-sama

\begin{tabular}{|c|c|c|c|c|c|c|}
\hline \multicolumn{7}{|c|}{$\operatorname{ANOVA}^{a}$} \\
\hline Model & & Sum of Squares & Df & Mean Square & $\mathrm{F}$ & Sig. \\
\hline 1 & $\begin{array}{l}\text { Regression } \\
\text { Residual } \\
\text { Total }\end{array}$ & $\begin{array}{l}191.964 \\
351.479 \\
543.443\end{array}$ & $\begin{array}{l}3 \\
93 \\
96\end{array}$ & $\begin{array}{l}63.988 \\
3.779\end{array}$ & 16.931 & $.000^{\mathrm{b}}$ \\
\hline
\end{tabular}

a. Dependent Variable: Kualitas Audit

b. Predictors: (Constant), Profeionalisme Auditor, Kompetensi, Independensi

\section{Lampiran 9 \\ Tabel 4.8 \\ Uji t}

\section{Coefficients $^{\mathrm{a}}$}

\begin{tabular}{|c|c|c|c|c|c|c|c|c|}
\hline \multirow{2}{*}{\multicolumn{2}{|c|}{ Model }} & \multicolumn{2}{|c|}{$\begin{array}{l}\text { Unstandardized } \\
\text { Coefficients }\end{array}$} & \multirow{2}{*}{$\begin{array}{l}\text { Standardiz } \\
\text { ed } \\
\text { Coefficien } \\
\text { ts } \\
\text { Beta }\end{array}$} & \multirow[t]{2}{*}{$\mathrm{T}$} & \multirow[t]{2}{*}{ Sig. } & \multicolumn{2}{|c|}{$\begin{array}{l}\text { Collinearity } \\
\text { Statistics }\end{array}$} \\
\hline & & B & $\begin{array}{l}\text { Std. } \\
\text { Error }\end{array}$ & & & & $\begin{array}{l}\text { Toleran } \\
\text { ce }\end{array}$ & VIF \\
\hline \multirow{4}{*}{1} & (Constant) & .866 & 3.411 & & .254 & .800 & & \\
\hline & Kompetensi & .091 & .053 & .151 & 1.703 & .092 & .889 & 1.125 \\
\hline & Independensi & .098 & .054 & .162 & 1.834 & .070 & .888 & 1.126 \\
\hline & $\begin{array}{l}\text { Profeionalisme } \\
\text { Auditor }\end{array}$ & .531 & .086 & .517 & 6.175 & .000 & .994 & 1.006 \\
\hline
\end{tabular}

a. Dependent Variable: Kualitas Audit

\section{Lampiran 10}




\section{Gambar 4.1}

Normal P-P Plot of Regression Standardized Residual

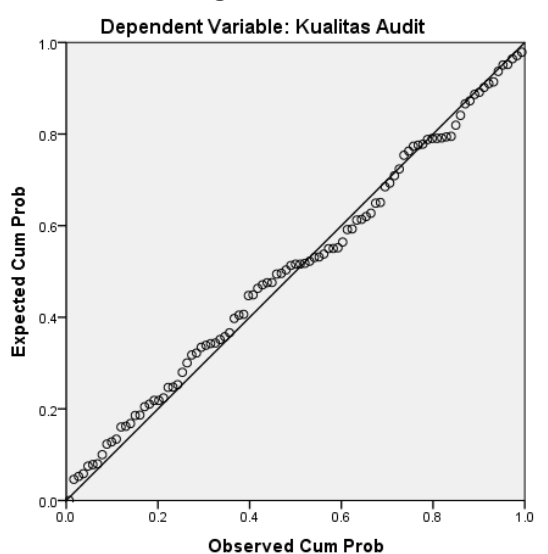

Sumber : Hasil Output SPSS

Lampiran 11

Uji Heteroskedastisitas

Scatterplot

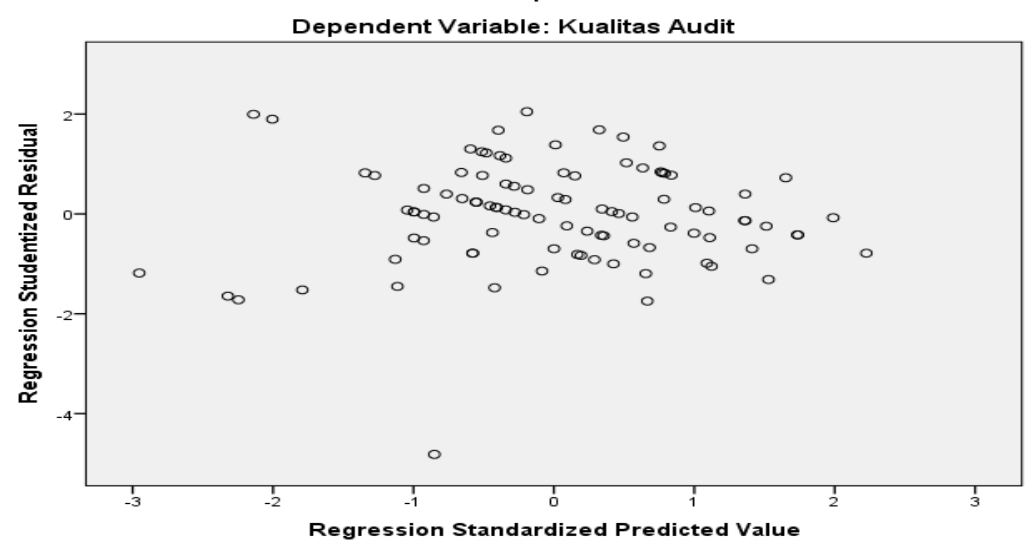

